The contributions by authors included in this issue may help readers establish a basis on which to begin dialogue and provide a platform for school professionals to begin to deliberate on how they might challenge administrators and faculties of education to provide training and education in these areas.

Julian Kitchen, assistant professor at Brock University reveals how his research and intervention strategy helped save a stressed out teacher's career. Catherine Kiteley, Clinical Nurse Specialist, Supportive Care at Credit Valley Hospital in Mississauga, Ontario, provides insights about handling workplace stress that are applicable to all professionals who provide care and support services to groups of patients, clients and students. Darlene Ciuffetelli Parker shares with readers her internship/mentorship experiences and the stress she experienced as a new professor at the Faculty of Education, Brock University. Music therapist, Adrienne Pringle introduces readers to the skills of a music therapist and how those skills can be applied in therapeutic settings. Mary Brownell of Florida State University provides educators with tips on reducing stress in the special education environment. Concluding this issue is an excerpt from a paper prepared by the National Education Association titled Violence in Communities and Schools: A Stress Reduction Guide for Teachers and other School Staff. Each of these articles provides readers with insights, strategies and tips for dealing with stress.

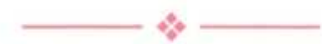

\title{
Overcoming the Stress Cycle through Relational Teacher Development
}

\section{Julian Kitchen}

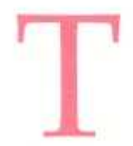

here is little doubt that teachers in Ontario, like their peers throughout the industrial world, have experienced considerable stress during an era of wholesale educational restructuring. When systemic change is compounded by school and personal factors, stress can become overwhelming for some teachers. Troman and Woods (2001), who conducted a qualitative study of twenty teachers who felt they were suffering from anxiety, depression or stress-related illness, reported the "drip, drip" effect of change and criticism meant that

"The teachers felt humiliated, tormented, disparaged and overloaded" (p.63).

This was partly attributable to principals who wanted "constant improvement", causing teachers to feel under "constant surveillance" as if

"Hidden cameras [were] watching them all the time" (p.67).

Many of Troman and Woods' participant felt "fear and humiliation" more than "care and collaboration" (p.70) in the face of the "powerful emotional relationship" between teachers and principals (p.63).

Hargreaves, who has studied changes to the nature of teachers' work, writes

"Teachers' emotions are rooted in and affect their selves, identities and relationships with others" (1998, p. 323).
As their emotions and identities are tied to their performance in the classroom, challenges to their professional competence may cause them to question their identities as caring persons committed to serving young people. This may contribute to a "stress cycle" in which exhaustion and frustration lead to worsening performance that, in turn, lead to diminished efficacy and energy (Troman \& Woods, 2001).

On the other hand,

"Teachers with rich opportunities to grow and learn are enthusiastic about their work and are motivated to find ways to do even better" (McLaughlin \& Yee, 1988, p. 28).

We need to foster, maintain and renew this positive attitude among teachers in a time of change. The level of exhaustion and burnout in the teaching profession (Beatty, 1999) has caused many experts to stress the need for constructive feedback (Rosenholtz, 1989), recognition (Troman \& Woods, 2001) and collegial support (Beatty, 1999) in order help teachers overcome stress and rise to the challenges of teaching in a "post-modern age" (Hargreaves, 1994).

In this paper, I recount the story of one elementary teacher, Bob Fitzgerald, who seemed locked in
"A stress cycle where exhaustion contributed to worsening teacher/pupil relationships which in turn induced further exhaus- tion and impacted on teacher effi- cacy" (Troman \& Woods, 2001). 
I then consider how my collaboration with this teacher contributed to his professional renewal.

\section{A Critical Incident}

Bob Fitzgerald had just transferred to Lippincott School when I began researching his classroom practices in September 1998. Over the course of the year, I visited Bob 56 times as part of my research into teacher knowledge and professional development. This was followed by 25 visits over the next three years.

Towards the end of October, the principal observed the class in order to evaluate Bob's performance. The principal was not impressed and conveyed this message when they met afterwards. Bob described the meeting to me at the end of the day:

The principal asked to see his lessons. He showed her his weekly planner. She then asked to see his unit plan for the Middle Ages. He did not have one written. Nor did he have them for other units. He told her that he was following the Ministry guidelines carefully and had a framework in his head. She said that this made it look like he was "flying by the seat of his pants". She wanted to see a unit plan for the Middle Ages by Monday. (Field Notes, October, 28, 1998)

I offered Bob support, noting that he had good ideas and had developed a positive class atmosphere. Rather than disagree with the feedback of the principal, I acknowledged that there was a basis for her impressions. I suggested that his core strengths would be more evident if he polished the surfaces and sharpened his skills so that he would be more successful. We discussed lesson planning, and I proposed that he ask a colleague for lesson and unit plans to review. (Field Notes, October 28, 1998).

Over the next few weeks, with my encouragement and support, Bob worked harder and performed more effectively. By January 1999, Bob had received a positive report from the principal. A year after the principal's visit, Bob declared, "Everyday is a pleasure" (Field Notes, October 28, 1999); this would become his mantra over the next few years. Today, he continues to enjoy teaching Grade 4 at Lippincott School, two years after he qualified for retirement on a full pension.

How had Bob changed? How had our collaborative relationship contributed to his renewal?

\section{Bob's Story}

Bob Fitzgerald was caught in a stress cycled when he transferred to Lippincott School.

A veteran of over twenty years, he had taught for eight years at Abbey Road, a brand-new school in an economically and ethnically diverse neighbourhood. Bob recalled these as rewarding years of devotion to students, as well as involvement in school-wide initiatives and extracurricular activities. Highlights included winning several school district chess championships and being recommended for a teaching award. Bob, however, chose to leave the school as part of a "mass exodus" after a change of principals.

Bob transferred to Penny Lane School, which was located in a neighbourhood of entrenched poverty. While Bob welcomed the challenge, he soon felt trapped in a constant struggle to maintain student safety and basic human respect. In particular, he became frustrated due to four or five students with behaviour issues who swore, refused to cooperate, and required constant attention. Efforts to maintain discipline resulted in less student-centred approach, which diminished satisfaction for teacher and students alike. Bob found teaching "less satisfying than before" and increasingly withdrew into himself. As Bob became more dissatisfied and increasingly isolated from his peers, the student misbehaviour escalated. Nonetheless, Bob received a positive five-year appraisal from his principal at the end of his first year.

Perhaps Bob, like many other teachers adapting to new and challenging school environments (Bullough \& Baughman, 1997), would have benefited from the support of professionals with greater situational knowledge. No assistance was sought or offered, according to Bob, who reported that the principal had never observed him teach. The situation took a turn for the worst in his second year, when the principal recommended that $\mathrm{Bob}$ leave the school. Discouraged and exhausted, Bob passively accepted an administrative transfer to Lippincott School.

\section{Accounting for Bob's Renewal}

Teachers are asked to develop classroom relationships that nurture "experiences that lead to growth" (Dewey, 1938), yet little attention is devoted to establishing contexts for authentic teacher development. The consequences are evident in the failure of school change initiatives over the years (e.g. Cuban, 1993; Fullan, 1993). 
Bob felt unsupported during his period of stress by the principals of Penny Lane and Lippincott schools. While the pressure applied by the principal of Lippincott School precipitated the crisis that broke Bob's stress cycle, he felt that she applied excessive pressure and offered little support.

Bob ultimately renewed himself, drawing on strengths that were evident in his past practice, yet he believed that he could not have broken the stress cycle and renewed his practice without assistance.

"I will be forever in your debt," declared Bob (Field Notes, May $15,2000)$. Bob identified my support as critical, his renewal, even though I offered little specific curriculum and instruction support. While I did assist Bob in learning to use the computerized report card system, development of this secondary teaching function could not account for the dramatic changes in Bob's delivery of core teaching functions such as lesson delivery, classroom management, and assessment. More important, according to Bob, was the quality of the professional relationship we developed while working on the computerized report cards. This would prove critical in enhancing Bob's self-efficacy and breaking the stress cycle in which he felt trapped.

Hollingsworth, Dybdahl and Minarik's (1993) identify "knowing through relationship to self and others" (p. 8) as central to growth for learners and teachers. In light of the limitations of large-scale, top-down professional development initiatives, Clark (2001), argues that there is a need for
"Research and development projects aimed at supporting teacher learning and development in tumultuous times" (p. 4).

Humanist psychologist Carl Rogers suggests that individuals benefit more from helpers who celebrate their experience and help them discover order in the flowing, changing process of life than from experts who judge them using external criteria (Rogers, 1961). Building on Rogers' conception, I developed the term relational teacher development to describe our nonjudgemental, trusting professional relationship. I also identified seven characteristics of our relationship that contributed to Bob's renewal, and to my growth as a teacher educator and educational researcher. These characteristics are:

1. Understanding One's Own Personal Practical Knowledge 2 Improving One's Practice in Teacher Development

3. Understanding the Landscape

4. Helping the Teacher Face a Problem

5. Respecting and Empathizing with the Teacher

6. Conveying that Respect and Empathy

7. Receptivity to Growing in Relationship

\section{Relational Teacher \\ Development in Action}

While my doctoral research was focussed on understanding teacher knowledge and how teachers adapt to change, it was not my intention to become involved in teacher development. This inquiry focus emerged accidentally as a result of my engagement in Bob's classroom and school (Kitchen, in press). While my graduate work in narrative inquiry (Clandinin \& Connelly,
2000) helped me respect the personal professional knowledge (Connelly \& Clandinin, 1988) of teachers as curriculum makers (Clandinin \& Connelly, 1992), my assistance was spontaneous, intuitive, and, at times, awkward. Relational teacher development is a retrospective frame for understanding the dynamics of our relationship. Below I briefly describe how each characteristic contributed to Bob's professional renewal.

\section{Understanding One's Own Personal Practical Knowledge}

After studying my experiences and those of others teachers, I had come to accept my own personal practical knowledge and respect the different experiences and beliefs of other teachers. Working with Bob helped me realize the importance of self-awareness in empathizing with and supporting the personal professional growth of other teachers.

\section{Improving One's Practice in Teacher Development}

In my work with Bob, I listened for his priorities and used my knowledge to help direct his energies towards achieving them. Knowledge of cutting-edge practices and current school district initiatives is important for individuals involved in teacher development. Much more important is the capacity to listen attentively to tailor teacher development to their needs.

\section{Understanding the Landscape}

By the time I had begun to help Bob with the computerized report cards, I was already familiar with Bob, his classroom and the school. 
This gave us common experiences and enabled me to both praise Bob's strengths and offer suggestions in a manner that was respectful of his teaching.

\section{Helping the Teacher Face a Problem}

While the use of computers was a low priority for Bob, successfully using the report card program became important as a way of proving himself to the principal. In a non-directive manner, I encouraged Bob to discuss his core beliefs and reflect on how he might adapt his daily practice to reflect these conceptions. Key was my trust in his "basically positive direction" (Rogers, 1961, p.26) and acceptance of his priorities..

\section{Respecting and Empathizing with the Teacher}

There were tensions between respect and judgment as I assisted Bob. Nevertheless, I respected Bob and did not have an image of the teacher he should become. Instead, I sought to help him develop into a more fully realized version of the teacher he sought to be. Through positive regard and congruence with Bob's goals (Rogers, 1961), I was better able to support Bob's self-concept and prompt him to consider ways in which he might constructively respond to the principal's concerns.

\section{Conveying that Respect and Empathy}

While respect and empathy are important, my relationship with Bob taught me that it is vital that

"The client should experience or perceive something of the therapist's congruence, acceptance and empathy" (Rogers, 1961, p. 284).
In contrast to the principal's ongoing criticism, my genuine respect and gentle encouragement helped Bob move from passivity and isolation to activity and, increasingly, community with his peers.

\section{Receptivity to Growing in Relationship}

Working with Bob helped me to appreciate the importance of receptivity to growing in relationship. I engaged with Bob in common pursuit of new meaning and enhanced practice. Through this process I also grew as a teacher educator and educational researcher. Deep commitment from both participants to growing is key to genuine teacher development relations.

\section{Educational Significance}

Teachers encounter considerable stress as they confront the challenges of teaching in a changing world. More attention needs to be directed at helping them to become curriculum makers who take charge of their own professional learning. Bob Fitzgerald overcame the stress cycle by learning to take charge of his own professional practice and development. The relational approach I adopted, by building on his personal practical knowledge rather than imposing solutions, helped him to become reenergized and more effective. While Bob's teaching is not cuttingedge, his students and colleagues regard him as an effective and caring teacher.

Relational teacher development provides a framework for a systematic orientation to teacher development that is rigorous yet sensitive to individual needs. The seven characteristics offer principals and teacher developers more authentic ways of responding to the needs of teachers.

All teachers benefit from relational teacher development as they cope with the effects of perpetual change. As they pass through various life and career stages (Huberman, 1993) or move between school (Bullough \& Baughman, 1997), they may be particularly susceptible to stress and, thus, in need of support. Also, new teachers need more support as they enter the profession (Stoel \& Thant, 2002). Using relational approaches in teacher education can help new teachers build on the expertise they already possess (Kitchen, 2005a; 2005b). Otherwise, concern for classroom survival may divert them from delving more deeply into effective classroom practice.

In all stages of their careers, teachers need opportunities to transition from survival through mastery to expertise (Huberman, 1993). Perhaps, by promoting "conversation, dialogue, and narrative" (Clark, 2001, p.4) from the beginning, we empower teachers to better cope with the stresses of teaching in times of change.

\section{Tips for Teachers Under Stress}

\section{Recognize that Careers are Dynamic}

As you move through different career and life stages, your needs and interests will change.

\section{Reflection is Vital}

Annually reflect on your career satisfaction. What do you enjoy? What do you dislike? What can you change?

\section{Be Proactive}

Engage in professional development, seek interesting oppor- 
tunities at your school, and consider changing schools.

\section{Ask for Help}

Seek informal and formal mentoring. Request employee assistance through the human resources department or your federation.

It is Never too Late (or too Early) to Renew

\section{A Challenge for School Districts}

While teachers are generally very good at self-renewal, some lose their ability to renew themselves. This may be due to personal or professional experiences, or a result of changes to personal and career stages. How can school districts protect their most vital resource?

\section{Support ongoing teacher development for self and professional renewal.}

- Coping with stress

- Understanding career and life stages

\section{Promote interesting opportunities for teachers}

- Becoming a mentor

- Engaging in special projects Encourage school principals as career coaches

- Celebrating and valuing day-to-day teaching

- Mentoring responsive to individual needs

\section{Advocate mentoring}

- Informal mentoring within professional learning communities

- Highly skilled mentors to support teachers at-risk.

\section{Additional Reading}

Educational Leadership, March 2006

Theme: Improving Professional Practice

A wide range of concise, thoughtful articles

Edutopia: www.edutopia.org

Go to Mentoring section

Features articles and courseware modules

\section{References}

Beatty, B. (1999). Teachers and their leaders: The emotionality of teachers' relationships with administrators. Presented to the International Study Association on Teachers and Teaching, Dublin, Ireland, June 1999.

Bullough, R.V. \& Baughman, K. (1997). "First-year teacher" eight years later: An inquiry into teacher development. New York: Teachers College Press.

Clandinin, D. J. \& Connelly, F. M. (2000). Narrative inquiry: Experience and story in qualitative research. San Francisco: Jossey-Bass.

Clandinin, D. J. \& Connelly, F. M. (1992). Teacher as curriculum maker.

In Philip Jackson (Ed.), Handbook of research in curriculum, pp.363-401. New York: MacMillan.

Clark, C. M. (2001). Talking shop: Conversations and teacher learning. New York: Teachers College Press.

Connelly, F. M. \& Clandinin, D. J. (1988). Teachers as curriculum planners. Toronto: OISE Press.

Cuban, L. (1993). How teachers taught: constancy and change in American classrooms, $1890-1990$ ( $2^{\text {nd }}$ Ed.). New York: Teachers College Press.

Dewey, J. (1938). Experience and education. New York, Collier Books.

Fullan, M. (1993). Change forces: Probing the depths of educational reform. London, United Kingdom: Falmer.

Hargreaves, A. (1998). The emotional politics of teaching and teacher development: with implications for education leadership, International Journal of Leadership in Education, 1(4): 315-336.

Hargreaves, A. (1994). Changing teachers, changing times: Teachers' work and culture in a post-modern age. Toronto, Ontario, Canada: OISE Press.

Hollingsworth, S., Dybdahl M., \& Minarik, L.T. (1993). By chart and chance and passion: the importance of relational knowing in learning to teach. Curriculum Inquiry, 23(1), 5-35.

Huberman, A.M. (1993). The lives of teachers. New York: Teachers College Press.

Kitchen, J. (2005a). Conveying respect and empathy: Becoming a relational teacher educator. Studying Teacher Education, 1(2), 194-207.
Kitchen, J. (2005b). Looking backwards, moving forward: Understanding my narrative as a teacher educator. Studying Teacher Education, 1(1), 1730.

Kitchen, J. (In Press). Setting the stage for field research: negotiating entry and understanding the school landscape. Alberta Journal of Educational Research, 52(4).

McLaughlin, M.W. \& Yee, S.M. (1988). School as a place to have a career. In A. Lieberman (Ed.) Developing the case for a professional culture. New York: Teachers College Press, 23-44.

Rogers, C. (1961). On becoming a person. Boston: Houghton Mifflin.

Rosenholtz, S.J. (1989). Workplace conditions that affect teacher quality and commitment: Implications for teacher induction programs, The Elementary School Journal, 420-439.

Stoel, C.F. \& Thant, T. (2002). Teachers' professional lives: A view from nine industrialized countries. Washington, D.C.: Council for Basic Education.

Troman, G. \& Woods, P. (2001). Primary teachers' stress. London, United Kingdom: Routledge Falmer.

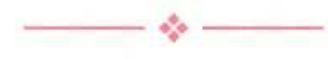

Julian Kitchen is a new assistant professor in the Faculty of Education, Brock University, where he teaches education law. Current research and writing are in the fields of teacher education, induction and development. $\mathrm{He}$ is the president of the Self-study in Teacher Education Special Interest Group of the Canadian Association of Teacher Educators, a member of the international advisory board of Studying Teacher Education, and an editor of Ontario Action Researcher. In seven years as a teacher educator at the University of Toronto, he taught preservice, additional qualification and graduate courses. 